\title{
Terbum
}

35 (2019) $507-536$

\section{Wojciech Pikor}

Uniwersytet Mikołaja Kopernika, Toruń

Wojciech.Pikor@umk.pl, ORCID: 0000-0003-2656-152X

\section{Postulat animacji Biblijnej}

DUSZPASTERSTWA W DOKUMENCIE PAPIESKIEJ

KoMISJI BibliJneJ INTERPRETACJA BIBLII

$W$ KOŚCIELE I W ADHORTACJI APOSTOLSKIEJ

BENEDYKTA XVI VERBUM DOMINI

\section{Postulate on the Biblical Animation of Pastoral Work in the Pontifical Biblical Commission's Document} The Interpretation of the Bible in the Church and in the Apostolic Exhortation Verbum Domini of Benedict XVI

Przedmiotem analizy jest dokument Papieskiej „Interpretacja Komisji Biblijnej Interpretacja Biblii w Kościele. Jest on najpierw odczytany w kontekście odnowy biblijnej, jaka miała miejsce w Kościele katolickim w XX wieku, w szczególności w związku z konstytucją Dei verbum Soboru Watykańskiego II. Nowością dokumentu PKB jest położenie większego akcentu na kwestię aktualizacji i inkulturacji Biblii, jak również zwrócenie uwagi na duszpasterską rolę wspólnot podstawowych podejmujących lekturę Pisma Świętego. Pewną słabością dokumentu Biblii w Kościele", adhortacja Verbum Domini, katecheza biblijna, odnowa biblijna, duszpasterstwo biblijne, inkulturacja, aktualizacja, apostolat biblijny 
Interpretacja Biblii $w$ Kościele jest zauważalny w nim brak współpracy biblistów z teologiami pastoralnymi. Ten mankament jest przezwyciężony w adhortacji Verbum Domini, której główny postulat zawiera się $\mathrm{w}$,ubiblijnieniu całego duszpasterstwa”. W konsekwencji adhortacja stwarza nowe możliwości animacji biblijnej duszpasterstwa, rozwijając i pogłębiając postulaty wysunięte wcześniej w dokumencie Interpretacji Biblii w Kościele.

Abstract

The first aim of the article is to place the document The Interpretation of the Bible in the Church within the context of the biblical renewal of the 20th century. Maintaining a continuity with the constitution Dei Verbum, the PBC puts in its document new elements which indicate the place of the Bible in the Church. It concerns mainly the actualization and inculturation of the Holy Scripture. Vital for pastoral work are recommendations on the biblical apostolate, above all those referring to basic communities that read the Bible. The analysis of the fourth chapter of the PBC's document also yielded some critical comments concerning the presented postulates. The weakness of this document is, without any doubt, the fact that it was written from the biblical scholarly point of view, without the collaboration of pastoral theologians of various specialities. This fundamental deficiency of the document The Interpretation of the Bible in the Church is absent in exhortation Verbum Domini. Postulates presented by Pope Benedict XVI referring to "biblical animation of all pastoral work" show that the Bible is not an addition to pastoral work, but rather its source and essence. Proposals contained in the
KeYWORDS

Interpretation of the Bible in the Church, Verbum Domini, biblical animation, biblical catechesis, biblical renewal, inculturation, actualization, biblical apostolate 
exhortation Verbum Domini give new opportunities for biblical animation in many areas of the life of Church.

25. rocznica ukazania się dokumentu Papieskiej Komisji Biblijnej Interpretacja Biblii w Kościele skłania do podjęcia nowej lektury tego tekstu, by uchwycić w nim to, co stanowi istotny wkład w rozwój studiów biblijnych i w życie Kościoła ${ }^{1}$. Za nowym odczytaniem tego dokumentu przemawia również fakt, iż jego recepcja - przynajmniej w Polsce - ograniczała się zasadniczo do jego pierwszej części poświęconej egzegezie biblijnej. Najsłabsze zainteresowanie budził ostatni rozdział zatytułowany „Interpretacja $\mathrm{Bi}$ blii w życiu Kościoła”. Taki wniosek nasuwa się chociażby po lekturze artykułów w pracach zbiorowych - pokłosiu konferencji naukowych, w których pomijano zasadniczo tę część pastoralną.

Potrzeba lektury tego dokumentu rodzi się również w perspektywie adhortacji apostolskiej Verbum Domini papieża Benedykta XVI z 30 września 2010 r. Takie spojrzenie jest konsekwencją hermeneutyki ciągłości w Kościele, która zakłada również poszukiwanie elementów nowych, nie tyle

1 Poniższy artykuł jest uzupełnioną wersją referatu wygłoszonego w języku angielskim podczas Międzynarodowej Konferencji Naukowej „The Interpretation of the Bible in the Church. The 25th Anniversary of the Pontifical Biblical Commission's Document" zorganizowanej przez Instytut Nauk Biblijnych Uniwersytetu Kardynała Stefana Wyszyńskiego w Warszawie w dniu 18 kwietnia 2018 r. Tekst referatu został opublikowany w materiałach pokonferencyjnych: W. Pikor, "Biblical Animation of All Pastoral Work in the Document The Interpretation of the Bible in the Church (1993) in the Perspective of the Exhortation Verbum Domini (2010)", Sources, Methods and Challenges. Biblical Studies 25 Years after Pontifical Biblical Commission's Document 'The Interpretation of the Bible in the Church' (red. D. Sztuk - Z. Grochowski - J. Kręcidło) (Biblica et Theologica TNFS 3; Warsaw: Towarzystwo Naukowe Franciszka Salezego 2018) 128-152. 
w sensie przewyższenia, ile raczej pogłębienia i rozwinięcia pewnych rozwiązań pastoralnych bazujących na Biblii, a wysuwanych wcześniej przez Magisterium Kościoła.

Proponowany artykuł, respektując hermeneutykę ciągłości, będzie miał na celu najpierw osadzenie dokumentu Interpretacja Biblii w Kościele w kontekście odnowy biblijnej XX wieku, następnie dokonanie jego oceny formalnej i merytorycznej, i wreszcie skonfrontowanie go $\mathrm{z}$ wizją animacji biblijnej duszpasterstwa nakreślonej w adhortacji Verbum Domini.

\section{InTERPRETaCJa BibLII W Kó́CIELE W KONTEKŚCIE ODNOWY BIBLIJNEJ W XX WIEKU}

Dokument Interpretacja Biblii w Kościele należy odczytywać w kontekście odnowy biblijnej i liturgicznej, które rozwijały się od początków XX wieku. Punktem kulminacyjnym jest bez wątpienia Sobór Watykański II, jednakże na potrzebę wykorzystania Biblii w życiu Kościoła zwracano uwagę już wcześniej.

Za magna charta duszpasterstwa biblijnego uznaje się encyklikę papieża Piusa XII Divino afflante Spiritu z 30 września 1943 r. (EB, 538-569). Dla odnowy biblijno-duszpasterskiej kluczowy okazał się paragraf zatytułowany „Różne sposoby wykorzystania [Pisma Świętego] w świętej posłudze” (EB 566)2. Papież podkreśla, że „na wiernych, a w szczególności na kapłanach, spoczywa wielkie zobowiązanie (grave officium) do szerokiego i świętego korzystania z tego skarbu [Pisma Świętego]”. Kapłani mają ,stymulować i podsycać poznanie i umiłowanie świętych Ksiąg wśród katolików” przez „kazania, homilie i egzorty”. Biskupi mają wspierać stowarzyszenia, których celem jest „rozpowszechnianie wśród wiernych egzemplarzy Pisma Świętego, szcze-

2 Został on syntetycznie omówiony w: Grzybek, „Pius XII a Biblia”, 472-473; Chmiel, „W 50. rocznicę wydania encykliki Divino afflante Spiritu", 173-174. 
gólnie świętych Ewangelii, oraz zabieganie z najwyższym zaangażowaniem, by $\mathrm{w}$ rodzinach chrześcijańskich miała miejsce regularnie każdego dnia właściwa i pobożna (rite sancteque) lektura [Biblii]". Jakby wyprzedzającym swoją epokę jest zalecenie, by korzystać tam, gdzie pozwala liturgia, z zaaprobowanych przez władzę kościelną przekładów Pisma Świętego na języki współczesne. Rozpowszechnianiu wiedzy biblijnej wśród wiernych ma służyć organizowanie wykładów i konferencji biblijnych, jak również publikacje w czasopismach, w których wyniki badań naukowych „będą uprzystępnianie (accommodandos) dla posługi świętej i dla duchowych korzyści wiernych".

Nowe spojrzenie na Pismo Święte w życiu Kościoła, nie tylko od strony dogmatycznej, ale również pastoralnej, przyniósł Sobór Watykański II. Jan XXIII w bulli zwołującej Sobór Watykański (Boże Narodzenie 1961) podkreślał jego duszpasterski charakter: „Współczesnemu światu trzeba ukazać na nowo ożywcze i niewyczerpane moce i ład Ewangelii”3. Ojcowie soborowi czynią to przede wszystkim w Konstytucji dogmatycznej o Objawieniu Dei verbum $\left(18.11 .1965\right.$, EB 669-708) ${ }^{4}$.

Określając swoją tożsamość w relacji do słowa Bożego, ojcowie soborowi wskazują na Pismo Święte i Tradycję jako najwyższą normę wiary (KO 10), uznają Pismo Święte za duszę całej teologii (KO 24), a przede wszystkim podkreślają „duszpasterskie znamię Biblii jako źródła chrześcijańskiego życia i wszelkiego przepowiadania"s. Zwrócenie uwagi na rolę Pisma Świętego w posłudze pastoralnej Kościoła bazuje na zrozumieniu natury samego Pisma, przez które dokonuje się Objawienie Boże. Objawienie nie jest czymś, co dokonało się w przeszłości, ale nieustannie dokonuje się w teraźniejszości. Przez słowo Pisma Bóg i Chrystus nie przestają prowadzić dialogu ze swoją Oblubienicą - Kościołem:

3 Jan XXIII, Aby byli jedno, 58.

Tekst polski: Sobór Watykański II, Konstytucje, dekrety, deklaracje, 48-78.

Muszyński, „Chrystus żyjący w swoim słowie”, 164. 
„W ten sposób Bóg, który niegdyś przemówił, bezustannie rozmawia z Oblubienicą swego umiłowanego Syna, a Duch Święty, dzięki któremu żywy głos Ewangelii rozbrzmiewa w Kościele, a przez Kościół w świecie, doprowadza wierzących do całej prawdy i sprawia, że słowo Chrystusa przebywa w nich obficie (por. Kol 3,16)" (KO 8).

Sposób obecności Pisma Świętego w Kościele zostaje podjęty w szóstym, zamykającym konstytucję rozdziale noszącym tytuł „Pismo Święte w życiu Kościoła”, w szczególności $\mathrm{w}$ nr. 22-26. Wysunięte tam postulaty naukowo-pastoralne można zestawić następująco ${ }^{6}$ :

1. „Jest rzeczą niezbędną, aby wierni Chrystusowi mieli szeroki dostęp do Pisma Świętego" (KO 22). Warunkiem tego dostępu są dobre, oparte na tekstach oryginalnych, przekłady Pisma Świętego, stosowane z myślą o liturgii, jak i w prywatnej lekturze.

2. Wskazane jest, by nowe tłumaczenia były wynikiem „wspólnego wysiłku z braćmi odłączonymi, by mogły być używane przez wszystkich chrześcijan" (KO 22; por. nr 25).

3. Udostępnienie wiernym wyników badań egzegetycznych prowadzonych „pod opieką Urzędu Nauczycielskiego Kościoła”, aby mogli otrzymać „pokarm Bożych Pism dla oświecenia umysłu, umocnienia woli i rozpalenia serc miłością Boga" (KO 23).

4. Staranne studium biblijne podejmowane przez wszystkie osoby pełniące posługę słowa w Kościele: kaznodziei, homiletów, katechetów i wszystkich innych nauczycieli chrześcijańskiej wiary, by „z powierzonymi sobie wiernymi dzielili się obfitym skarbem Bożego słowa” (KO 24-25).

5. Wszyscy wierni winni „ochoczo przystępować do świętego tekstu czy to za pośrednictwem świętej liturgii obfitującej w Boże słowa, czy też przez pobożne czytanie" (KO 25)

6 Witczyk, „W czterdziestolecie konstytucji Dei verbum”, 143-144.

7 Rodzi się problem interpretacji tej zachęty do lektury Pisma Świętego przez wszystkich wiernych. Zdaniem H. Witczyka ojcowie soborowi mają na myśli „„zytanie duchowe, które byłoby odnowioną wersją lectio” („W czter- 
6. Przybliżanie słowa Bożego wiernym ma się wreszcie dokonywać „przez odpowiednie instytucje i inne pomoce, które za przyzwoleniem i pod opieką pasterzy Kościoła chwalebnie się upowszechniają w naszych czasach" (KO 25).

Powyższe sugestie płynące z konstytucji Dei verbum ukazują wspólnotę Kościoła jako jeden organizm, w którym studium naukowe Biblii znajduje praktyczne przełożenie na posługę pastoralną w Kościele. W wymiarze osobowym niezbędna jest odpowiednia formacja biblijna nie tylko wiernych, ale przede wszystkim osób pełniących posługę słowa w Kościele. Czytanie Pisma Świętego ma być ukierunkowane w stronę lektury duchowej, której towarzyszy modlitwa będąca rozmową człowieka z Bogiem (KO 25). Istotnym postulatem duszpasterskim jest budowanie w Kościele struktur instytucjonalnych, które, autoryzowane przez pasterzy Kościoła, będą podejmowały się dzieła ubiblijniania duszpasterstwa oraz przybliżania skarbu Bożego słowa wszystkim członkom Kościoła.

\section{INTERpretacja Bibli W Kó́CIELE JAKO DOPEENIENIE ODNOWY BIBLIJNEJ W XX WIEKU}

Konstytucja Dei verbum wskazała pewne linie pastoralne, dzięki którym posoborowa odnowa biblijna nie pozostała tylko w sferze postulatów, lecz otrzymała konkretne przełożenie na życie Kościoła, myśląc przede wszystkim o liturgii, katechezie, formacji biblijnej przyszłych kapłanów i ekumenizmie. Dopełnieniem tych działań jest dokument Papieskiej Komisji Biblijnej Interpretacja Biblii w Kościele, ogłoszony przez Jana Pawła II 23 kwietnia 1993 r. (EB 1259-1560) ${ }^{8}$.

dziestolecie konstytucji Dei verbum”, 144; por. Kudasiewicz, „Proforystyka pastoralna”, 241). Uszczegółowienie tej zachęty w kierunku lectio divina nastąpi dopiero w dokumencie Interpretacja Biblii w Kościele.

8 Polski przekład: Interpretacja Biblii w Kościele, 24-100. 


\subsection{Propozycje pastoralne $\mathrm{w}$ dokumencie Interpretacja Biblii w Kościele}

Zasadniczym celem dokumentu PKB jest zwięzły przegląd metod stosowanych we współczesnej egzegezie, by mieć rozeznanie co do ich możliwości i granic w interpretacji tekstu biblijnego. Promulgując ten dokument, Jan Paweł II podkreśla, że „jeśli głównym zadaniem egzegezy jest uzyskanie autentycznego sensu sakralnego tekstu lub jego różnych sensów, to trzeba, żeby komunikowała ten sens adresatowi Pisma Świętego, którym jest, w miarę możliwości, każda ludzka osoba" . Wychodząc naprzeciw temu postulatowi, ostatnia część tego dokumentu (rozdz. IV) poświęcona jest „Interpretacji Biblii w życiu Kościoła”. We wprowadzeniu do tego rozdziału pojawiają się zdania, które podążają za optyką pastoralną konstytucji Dei verbum: „Kościół w rzeczy samej nie uważa Biblii tylko za zespół historycznych dokumentów dotyczących jego pochodzenia. Przyjmuje ją jako słowo Boga skierowane do niego i całego świata w obecnych czasach. To przekonanie wiary przenosi w konsekwencji w praktykę aktualizacji i inkulturacji orędzia biblijnego, jak również różne sposoby wykorzystania natchnionych tekstów w liturgii, lectio divina, posłudze duszpasterskiej i ruchu ekumenicznym" (IBK IV). Jest zatem uzasadnione twierdzenie, że IV rozdział dokumentu PKB stanowi „wykładnię soborowej konstytucji Dei verbum nr $24{ }^{\prime 10}$. Dokonuje jej jednak w szerszym kontekście hermeneutycznym.

\subsubsection{Kwestie hermeneutyczne}

Wskazuje na to sposób omówienia obecności Biblii w życiu Kościoła. Poruszone zostają bowiem na pierwszym miejscu kwestie stricte hermeneutyczne: aktualizacja i inkulturacja,

9 Jan Paweł II, „Przemówienie na temat interpretacji Biblii w Kościele”, 19.

10 Chmiel, „Pismo święte w duszpasterstwie”, 273. 
które kładą pewien fundament pod interpretację Biblii w ramach posługi duszpasterskiej i dialogu ekumenicznego. Te dwa filary hermeneutyczne pozwalają na obecność Biblii w życiu Kościoła każdego czasu i miejsca: dzięki „aktualizacji Biblia jest płodna w różnych czasach”, zaś „inkulturacja zapewnia zakorzenienie orędzia biblijnego na najróżniejszych terenach" (IBK IV.B). PKB podpowiada metodologię aktualizacji, która winna dokonywać się „,w trzech etapach: (1) słuchanie słowa wychodzące z obecnej sytuacji; (2) rozpoznanie aspektów obecnej sytuacji, które tekst biblijny naświetla lub kwestionuje; (3) wydobycie z pełnego sensu tekstu biblijnego elementów zdolnych płodnie przekształcić obecną sytuację, zgodnie ze zbawczą wolą Boga w Chrystusie" (IBK IV.A.2). Istotne jest zwrócenie uwagi na pewne uwarunkowania aktualizacji, które są szczegółowo rozpisane w punkcie IV.A.3 („Granice”) ${ }^{11}$, jakkolwiek o wiele ważniejsze wydaje się wskazanie poczynione we wcześniejszym punkcie, iż „aktualizacja nie może być poprawna bez usytuowania jej wobec tajemnicy Chrystusa i Kościoła” (IBK IV.A.2).

W przypadku inkulturacji PKB wskazuje na trzy etapy procesu interpretacyjnego Biblii (IBK IV.B). Pierwszy związany jest z przekładem Pisma Świętego, co przy przejściu na inny język „pociąga za sobą zmianę kontekstu kulturowego”. W drugim etapie następuje odczytanie orędzia biblijnego stosownie do „sposobów odczuwania, myślenia, życia i wypowiadania się właściwych dla kultury lokalnej”. Ostatni etap zmierza do „kształtowanie lokalnej kultury chrześcijańskiej przez słowo Boże”. W tym kontekście PKB podkreśla, że w inkulturacji „nie chodzi o proces jednokierunkowy, ale o wzajemne ubogacanie się"12.

11 Podstawowe błędy aktualizacji biorą się z „selektywnej lektury Biblii”, „założeń teoretycznych niezgodnych z podstawową orientacją Biblii” oraz z odrzucenia w interpretacji tekstów biblijnych „sprawiedliwości i miłości Ewangelii” (IBK IV.A.3).

12 To wzajemne ubogacenie oznacza „odrzucenie elementów szkodliwych [w danej kulturze - W.P.] i sprzyjanie rozwojowi elementów wartościo- 


\subsubsection{Biblia w liturgii}

Po przedstawieniu zasad hermeneutycznych aktualizacji i inkulturacji PKB przechodzi do zasadniczej dla tematu animacji biblijnej kwestii korzystania z Biblii w liturgii (IBK IV.C.1), lectio divina (IBK IV.C.2) i posłudze duszpasterskiej, w której wyróżnia katechezę, przepowiadanie oraz apostolat biblijny (IBK IV.C.3).

W kwestii liturgii PKB podąża tropem wskazanym przez nauczanie soborowe i posoborowe. Podkreśla na pierwszym miejscu, iż „liturgia a w szczególności liturgia sakramentalna [...] zasadniczo realizuje najdoskonalszą aktualizację tekstów biblijnych, ponieważ umiejscawia ich proklamację pośrodku społeczności wierzących zebranych wokół Chrystusa, by zbliżyć się do Boga" (IBK IV.C.1), w czym nawiązuje do $K L$ 7. Dalej PKB wskazuje na znaczenie nowego lekcjonarza, który „winien pozwolić na lekturę Pisma Świętego obfitszą, bardziej urozmaiconą i bardziej dostosowaną"13. Hermeneutyka ciągłości zauważalna w postrzeganiu miejsca Biblii w liturgii otrzymuje też ważne dopowiedzenia, które można sprowadzić do dwóch punktów:

- „liturgia Słowa nie polega na prostym następowaniu lektur, ponieważ powinna zawierać również czas milczenia i modlitwy";

- „przygotowanie do uczestnictwa w liturgii [jest] związane z praktyką lektury Pisma Świętego", co wymaga również „formacja przyszłych przewodniczących zgromadzeń i ich otoczenia" 14 .

wych”, jak również unikanie „synkretycznego pomieszania pojęć”.

13 PKB cytuje tutaj KL 35.

$14 \mathrm{Za}$ trzecie dopowiedzenie można by uznać podkreślenie, iż „homilia, która wyraźniej aktualizuje Słowo Boże, stanowi integralną część liturgii”, jakkolwiek ten element PKB omówi szerzej w IBK IV.C.3. 


\subsubsection{Biblia w lectio divina}

W przypadku lectio divina PKB dokonuje interpretacji postulatu „pilnego czytania duchowego” i „pobożnego czytania” Biblii wysuniętego przez Sobór Watykański II w KO 25. PKB przez lectio divina rozumie „lekturę indywidualną lub wspólnotową dłuższego lub krótszego tekstu Pisma Świętego przyjętego jako Słowo Boże, która rozwija się w czasie medytacji, modlitwy i kontemplacji za poruszeniem Ducha" (IBK IV.C.2). W dokumencie zostaje przywołany krótki rys historyczny lectio divina, który obejmuje najpierw wiek III po Chr. i praktykę lektury Biblii podejmowaną przez Orygenesa, następnie odrodzenie lectio divina w środowiskach monastycznych i wreszcie odwołanie się do tej praktyki w czasach współczesnych w Instrukcji Komisji Biblijnej De Scriptura sacra recte docenda z 1950 r. (EB 592) oraz KO 25. W tym ostatnim dokumencie PKB podkreśla „pewną nowość" w zachęcie skierowanej do „wszystkich wiernych Chrystusa, by nabyli poprzez częste czytanie Pism Bożych «doskonałe poznanie Jezusa Chrystusa ( Fpl 3,8)".

\subsubsection{Biblia w katechezie}

Prezentując Biblię w posłudze duszpasterskiej (IBK IV.C.3), PKB nie ogranicza się tylko do kwestii hermeneutycznych, lecz daje liczne praktyczne sugestie pastoralne. W przypadku katechezy PKB podkreśla źródłowy dla niej charakter Pisma Świętego: „Egzegeza Słowa Bożego w katechezie ma za pierwsze swoje źródło Pismo Święte, które objaśnianie w kontekście Tradycji daje punkt wyjścia, fundament i normę nauczania katechetycznego". PKB definiuje cel katechezy korzystającej z Biblii jako „wprowadzenie do głębszego rozumienia Biblii i do owocnej lektury, która pozwala odkryć zawarta w niej prawdę Bożą, pobudzającą do odpowiedzi [...] na orędzie Boga”. Ten dialogiczny cel lektury Biblii na katechezie zostaje dookreślony w kontekście Ewangelii 
jako „spowodowanie spotkania z Chrystusem, który daje klucz do całego objawienia biblijnego i przekazuje Boże wezwanie, na które każdy winien odpowiedzieć".

Gdy chodzi o praktyczną realizację tych celów, PKB stwierdza, że „katecheza winna wychodzić z kontekstu historycznego objawienia Bożego, żeby przedstawić osoby i zdarzenia Starego i Nowego Testamentu w świetle planu Bożego”. „Żeby przejść z tekstu biblijnego do znaczenia zbawczego dla obecnych czasów, wykorzystuje się rozmaite hermeneutyki, które inspirują różne komentarze. Płodność katechezy zależy od wartości hermeneutyki”. Zasygnalizowany zostaje również właściwy dobór tekstów biblijnych na katechezie. Zdaniem PKB katecheza „korzysta przede wszystkim z opowiadań Nowego, jak i Starego Testamentu. Kładzie nacisk na Dekalog”. Tymczasem należałoby „korzystać również z przepowiadania proroków, nauk ksiąg mądrościowych i wielkich mów ewangelicznych, jak Kazanie na Górze”.

\subsubsection{Biblia w przepowiadaniu}

Również praktycznie podchodzi PKB do posługi kaznodziejskiej. Jako cel przepowiadania wskazuje „wyciągnięcie ze starożytnych tekstów pokarmu duchowego odpowiedniego do aktualnych potrzeb wspólnoty chrześcijańskiej”. Następnie PKB formułuje pewne zasady, które winny być respektowane w przepowiadaniu:

- wyjaśnienie tekstów „nie może być zbyt szczegółowe”, gdyż chodzi o „naświetlenie głównych ich elementów”;

- „przedstawiając te elementy, należy dokonać aktualizacji inkulturacji”;

- należy unikać „bycia zadowolonym z moralizowania lub mówienia o współczesnych kwestiach w sposób uniemożlwiający rzucenia na nie światła słowa Bożego";

- „orędzie biblijne winno zachować swój główny charakter dobrej nowiny zbawienia ofiarowanej przez Boga”. 


\subsubsection{Apostolat biblijny}

Podejmując temat apostolatu biblijnego (IBK IV.C.3), PKB rozwija w istotny sposób postulowane przez Dei Verbum powstanie „odpowiednich instytucji i innych pomocy” $\mathrm{w}$ celu uprzystępnienia wiernym skarbca słowa Bożego (KO 25). W nawiązaniu do tego PKB kreśli zadania, jakie stoją przed „apostolatem biblijnym mającym za przedmiot rozpowszechnianie Biblii jako słowa Bożego i źródła życia”. Są one następujące:

- „przekład Biblii na najrozmaitsze języki i rozpowszechnianie tych przekładów";

- „formacja grup biblijnych, tygodnie biblijne, publikacje czasopism, książek itd.”;

- promocja „stowarzyszeń i ruchów kościelnych, które stawiają na pierwszym planie lekturę Biblii w perspektywie wiary i chrześcijańskiego zaangażowania”;

- wspieranie „wspólnot podstawowych organizujących zebrania wokół Biblii i stawiających sobie potrójny cel: poznać Biblię, ustanowić wspólnotę i służyć ludowi”;

- „głoszenie słowa Bożego i propagowanie poznania Biblii za pośrednictwem środków masowego przekazu, prasy, radia, telewizji”.

\subsubsection{Biblia w ruchu ekumenicznym}

Jako ostatni obszar korzystania z Biblii w Kościele zostaje wskazany przez PKB ekumenizm (IBK IV.C.4). PKB stwierdza, iż „większość problemów, które napotyka ruch ekumeniczny ma związek z interpretacją tekstów biblijnych". Jednakże „dzięki zastosowaniu tych samych metod i analogicznych celów hermeneutycznych egzegeci różnych wyznań doszli do wielkiej zbieżności w interpretacji Pisma Świętego". Jako działanie praktyczne na niwie ekumenizmu PKB proponuje:

- „umożliwienie jak największej liczbie chrześcijan nabycie Biblii"; 
- „popieranie przekładów ekumenicznych”;

- „propagowanie grup modlitwy ekumenicznej”.

Podsumowując prezentację IV rozdziału dokumentu Interpretacja Biblii $w$ Kościele, należy zauważyć, iż dla PKB obecność Biblii w Kościele stanowi najpierw problem hermeneutyczny, który wymaga zadbania o właściwą aktualizację i inkulturację słowa Bożego w świecie. Podejmując postulaty pastoralne zarysowane w konstytucji Dei verbum, PKB proponuje konkretne sposoby wykorzystania Biblii w liturgii, lectio divina i apostolacie biblijnym, podając zarazem pewne zasady konieczne dla owocnej obecności Biblii w tych przestrzeniach życia Kościoła.

\subsection{Ocena postulatów pastoralnych dokumentu Interpretacja Biblii w Kościele}

Zaprezentowane powyżej główne wskazania pastoralne dokumentu Interpretacja Biblii w Kościele nie doczekały się w polskiej biblistyce krytycznej analizy ${ }^{15}$. Nie ma wątpliwości, że PKB wykonała olbrzymi krok w przód w ukonkretnieniu obecności Biblii w posłudze pastoralnej Kościoła. Nie znaczy to jednak, iż tekst ten można uznać za programowy dla animacji biblijnej duszpasterstwa.

\subsubsection{Problem struktury IBK IV}

Pierwsza uwaga odnosi się do struktury IV rozdziału dokumentu Interpretacja Biblii w Kościele. Dwie pierwsze części

15 W'śód publikacji omawiających IV rozdział IBK należy wskazać: Chmiel, „Pismo święte w duszpasterstwie”, 273-279; Haręzga, Biblia $w$ Kościele (praca zbiera artykuły publikowane wcześniej w innych miejscach: „Znaczenie dokumentu Papieskiej Komisji Biblijnej Interpretacja Biblii w Kościele”, 19-25; „Droga Słowa Bożego od jego zrozumienia do inkulturacji”, 27-43; „Ku pogłębionej odnowie biblijnej”, 49-53); Pytel, „Wykorzystanie Pisma Świętego w Lectio divina”, 218-222. Dodać należy, że w pracy zbiorowej pod red. D. Piekarz, $Z$ badań nad Biblią, brak jakiegokolwiek artykułu odnoszącego się do IBK IV. 
tego rozdziału dotyczą kwestii związanych z aktualizacją $\mathrm{i}$ inkulturacją Biblii, co pozwala PKB na usytuowanie propozycji pastoralnych w szerszym kontekście hermeneutycznym. Problemem są kategorie pastoralne wskazane dalej przez PKB: liturgia, lectio divina, posługa duszpasterska i ruch ekumeniczny. Wątpliwości biorą się z tego, że homilia, stanowiąca integralną część liturgii Słowa w Eucharystii, została wprawdzie zasygnalizowana przy okazji liturgii (IBK IV.C.1), ale PKB omawia ją szczegółowo w ramach punktu dotyczącego posługi duszpasterskiej, w której porusza również kwestie związane z katechezą i apostolatem biblijnym (IBK IV.C.3). Jeszcze trudniej o uznanie lectio divina za kategorię posługi pastoralnej według standardów teologii pastoralnej.

Dokonany przez PKB podział obrazujący „różne sposoby wykorzystania natchnionych tekstów w Kościele" (IBK IV) nie jest metodologicznie spójny. Jest to wyzwanie znane samym teologom pastoralnym, którzy zgodnie z tradycyjnym podziałem rozróżniają duszpasterstwo zwyczajne i nadzwyczajne. To pierwsze jest adresowane do wszystkich wierzących i obejmuje posługę nauczania (m.in. katechizację i przepowiadanie słowa), uświęcenia (liturgia) i pasterską (wezwanie wszystkich ochrzczonych do świadectwa i do apostolatu $)^{16}$. Gdyby przyąć taką strukturę w IBK IV, wówczas podział byłby nie tylko klarowniejszy, ale również wolny od powtórzeń (por. homilia) i błędnych kategoryzacji (do posługi uświęcenia zaliczałaby się liturgia, homilia i lectio divina, zaś do posługi pasterskiej - posługa duszpasterska i ruch ekumeniczny).

\subsubsection{Problematyczne ujęcie liturgii}

Problem właściwego podziału aktywności pastoralnej Kościoła w dokumencie PKB zdaje się wskazywać na poważniej-

16 Por. Teologia pastoralna. II. Teologia pastoralna szczegótowa, 131. 
sza kwestię, jaką jest brak współpracy i konsultacji członków PKB z teologami specjalności pastoralnej w tworzeniu IBK IV. Zauważa się to przede wszystkim przy prezentacji obecności Biblii w liturgii i w katechezie.

W przypadku liturgii PKB sprowadza obecność tekstu Pisma Świętego „w szczególności [do] liturgii sakramentalnej", którą utożsamia z Eucharystią (IBK IV.C.1). Tymczasem wypada dostrzec wiele możliwości korzystania z Biblii w celebracji sakramentu pokuty czy sakramentu chorych. Liturgiści zaprotestują przeciwko wydzieleniu homilii z liturgii i umieszczeniu jej w ramach tzw. posługi duszpasterskiej (IBK IV.C.3). Tymczasem homilia jest integralną częścią liturgii Słowa w Eucharystii. Omawiając układ czytań mszalnych w nowym lekcjonarzu (IBK IV.C.1), PKB podkreśla, że „często sugeruje on interpretację skrupturystyczną za pomocą typologii”. Liturgiści widzieliby w doborze czytań cyklu niedzielnego klucz kanoniczny (chrystologiczny) ${ }^{17}$.

\subsubsection{Zastrzeżenia wobec rozumienia katechezy}

O nieznajomości tematu katechezy przez członków PKB można mówić po lekturze fragmentu poświęconego katechezie w ramach paragrafu „Biblia w posłudze duszpasterskiej” (IBK IV.C.3). W opinii PKB „egzegeza Słowa Bożego w katechezie [...] daje punkt wyjścia, fundament i normę nauczania katechetycznego". Pytanie: czy źródłem katechezy jest egzegeza słowa Bożego, czy też samo Pismo Święte? ${ }^{18}$.

Członkowie PKB zdają się nie być zorientowani we wskazaniach Dyrektorium ogólnego o katechizacji dotyczącego doboru tekstów biblijnych na katechezie ${ }^{19}$, jak również

17 Por. Janicki, „Obrzędy liturgii Mszy świętej”, 281-282.

18 Odpowiedź jest oczywista, na co wskazuje Dyrektorium ogólne o katechizacji z 1997 r.: „Słowo Boże jest źródłem, z którego katecheza czerpie swoje orędzie" (DOK 94).

19 Dyrektorium jest adaptowane do warunków Kościoła lokalnego. W Polsce obowiązuje Dyrektorium katechetyczne Kościota katolickiego w Polsce 
w praktyce aplikacji tych wskazań do programów ramowych nauczania religii, skoro piszą, że katecheza „korzysta przede wszystkim z opowiadań Nowego, jak i Starego Testamentu. Kładzie nacisk na Dekalog. Powinna czuwać, aby korzystać również z przepowiadania proroków, nauk ksiąg mądrościowych i wielkich mów ewangelicznych, jak Kazanie na Górze”. Co PKB rozumie przez „opowiadania Starego i Nowego Testamentu"? Jakie opowiadania ma na myśli? W jakim stopniu PKB ma świadomość, że w katechezie Dekalog znajduje swoje dopełnienie w analizie Ośmiu Błogosławieństw ?20.

Problematyczna jest też propozycja sposobu odczytania „znaczenia zbawczego [tekstów biblijnych] dla obecnych czasów”. W tym celu „wykorzystuje się rozmaite hermeneutyki, które inspirują różne komentarze. [...] Istnieje niebezpieczeństwo zadowolenia się powierzchownym komentarzem, który ogranicza się do rozważań chronologicznych następstwa wydarzeń i osób biblijnych”. Z tego fragmentu można wnioskować, że dla PKB hermeneutyka w wypadku katechezy sprowadza się do komentarzy biblijnych. PKB nie podpowiada żadnego pomysłu na przejście od tekstu biblijnego do jego znaczenia zbawczego ${ }^{21}$. W tej kwestii warto by skorzystać z wypracowanych już przez katechetyków modeli katechezy biblijnej ukierunkowanej antropologicznej ${ }^{22}$.

Poruszony wyżej wątek hermeneutyki na katechezie rodzi pytanie o to, w jakim stopniu osoby odpowiedzialne za redakcję paragrafu „Obecność Biblii w posłudze duszpasterskiej: katecheza" (IBK IV.C.3) miały na uwadze wcześ-

wydane przez Konferencję Episkopatu Polski w 2001 r. Na temat doboru tekstów biblijnych na katechezie: DOK 58-61.

20 Zauważa to zresztą sama PKB w dokumencie Biblia a moralność. Biblijne korzenie postępowania chrześcijańskiego z 2008 r., który otwiera Dekalogiem i Ośmioma Błogosławieństwa jako tekstami programowymi dla chrześcijańskiej moralności.

21 Ma się wręcza wrażenie, że PKB sprowadza katechezę do rodzaju wykładu biblijnego czy historii biblijnej.

22 Por. Klich, Pismo Święte w polskiej katechezie posoborowej, 74-91. 
niejsze rozdziały dokumentu Interpretacja Biblii w Kościele, szczególnie te dotyczące nowych analiz i podejść do tekstu biblijnego, które preferują lekturę synchroniczną Biblii, a przede wszystkim analizę narracyjną.

\subsubsection{Problem rozumienia lectio divina}

Zastrzeżenia odnośnie do metody katechezy bazującej na Biblii można kierować również do fragmentu dokumentu $\mathrm{PKB}$, w którym omawia się „korzystanie z Biblii w lectio divina" (IBK IV.C.2). Brakuje tu wskazań metodologicznych, które byłby możliwe do podjęcia przez „wszystkich wiernych Chrystusa”, by „nabyli przez częste czytanie Pisma Świętego doskonałe poznanie Chrystusa (Flp 3,8)"23. Skoro lectio divina ma być metodą „lektury indywidualnej lub wspólnotowej dłuższego lub krótszego tekstu Pisma Świętego" przez wszystkich chrześcijan, warto zaproponować praktyczne wskazówki do takiej lektury w kontekście życia nie-monastycznego.

\subsubsection{Pytania o sposób korzystania z materiałów źródłowych}

Kolejna uwaga krytyczna dotyczy nie do końca rzetelnego wykorzystania źródeł, na które powołuje się PKB w swoim dokumencie. Pozostając przy lectio divina, PKB, kiedy przedstawia rys historyczny tej metody, przywołuje na koń$\mathrm{cu}$ jako dokument zachęcający do lectio divina Instrukcję Komisji Biblijnej De Scriptura sacra recte docenda z 1950 r. (EB 592). Problem tylko w tym, że ta Instrukcja postuluje w tym miejscu, w ramach formacji zakonnej i seminaryjnej, „codzienną lekturę [Pisma Świętego], czynioną bez przerwy i na sposób systematyczny, [...] dodając do każdej księgi krótki prospekt lub analizę, jak to się czyni we «wprowadzeniu

23 Tę myśl PKB powtarza za KO 25. 
szczegółowym »". Nie jest też prawdą, że dopiero Sobór Watykański II („, tu jest pewna nowość” - IBK IV.C.2) zachęca do częstego czytania Pisma Świętego. Wystarczy tylko zajrzeć do przypisów towarzyszących KO 25 , by zorientować się, że ojcowie soborowi odsyłają m.in. do encykliki Spiritus paraclitus Benedykta XV (EB 475-480) i do encykliki Divino afflante Spiritu Piusa XII (EB 544), inspirując się z tej pierwszej przykładowo zdaniem: „Niech wszyscy podejmują zwyczaj czytania i medytowania [Ewangelii i Dziejów Apostolskich] każdego dnia" (EB 478), cytowanym później w encyklice Divino afflante Spiritu (EB 544).

Pozostając w temacie sięgania po źródła, trzeba zauważyć, że nie wiadomo, na jakiej podstawie PKB wyraża dość ostrą opinię na temat ujawnienia przez nowy lekcjonarz faktu nieznajomość Biblii przez katolików: „Jednakże jego istnienie miało dobroczynne skutki ekumeniczne. W niektórych krajach okazało się również, jak mało katolicy znają Pismo Święte" (IBK IV.C.1).

Podobny brak precyzji pojawia się również w kontekście niektórych propozycji pastoralnych. Była już wspomniana wyżej katecheza. Przywołać należy również sugestię, którą PKB kończy omawianie Biblii w liturgii. Zwraca uwagę na konieczność „uwzględnienia w formacji przyszłych przewodniczących zgromadzeń i ich otoczenia wymogów zdecydowanie odnowionej liturgii Słowa Bożego" (IBK IV.C.1). Znowu pytania: o jakie wymogi chodzi? Kto kryje się za pojęciem „otoczenia przewodniczącego zgromadzenia”?

Zabrakło PKB również konkretności przy omawianiu nowego lekcjonarza, który okazuje się, że „obecnie tylko po części odpowiada on ukierunkowaniu na lekturę Pisma Świętego obfitszą, bardziej urozmaiconą i bardziej dostosowaną" (IBK IV.C.1). Oczekiwałoby się, że PKB zaproponuje pewne zmiany chociażby w dobrze czytań w liturgii Słowa ${ }^{24}$.

24 Por. Sławiński, „Znaczenie lekcjonarza mszalnego w kaznodziejstwie”, 393-394. 
Reasumując ocenę propozycji pastoralnych w dokumencie Interpretacja Biblii w Kościele, należy podkreślić, iż stanowią one istotne dopełnienie postulatów wysuwanych wcześniej, przede wszystkim w konstytucji Dei verbum. Zastrzeżenia dotyczą najpierw instrumentalnego spojrzenia PKB na Biblię w duszpasterstwie. Wątpliwości budzi również sposób usystematyzowania działalności pastoralnej wykorzystującej Biblię. Szczegółowe propozycje dotyczące obecności Biblii w liturgii, katechezie czy przepowiadaniu są pisane z perspektywy biblistów, którzy nie zawsze są zorientowani w danym obszarze teologii pastoralnej. Do tego odnosi się wrażenie, iż autorzy IV rozdziału dokumentu jakby nie do końca byli świadomi uwag i propozycji metodologicznych poczynionych w rozdziałach wcześniejszych, co zauważa się szczególnie w kontekście katechezy biblijnej.

\section{Adhortacja Verbum Domini w dialogu $\mathrm{Z}$ DOKUMENTEM INTERPRETACJA BIBLII W KOŚCIELE}

Papież Benedykt XVI 30 września 2010 r. przekazał wspólnocie Kościoła adhortację apostolską Verbum Domini. Jest ona pokłosiem XII Synodu Biskupów poświęconego „Słowu Bożemu w życiu i misji Kościoła”, który miał miejsce w Rzymie w dniach 5-26 października 2008 r. Liczba odniesień w adhortacji Verbum Domini do dokumentu Interpretacja Biblii $w$ Kościele jest znacząca: dwanaście razy są to cytaty, zaś trzykrotnie czynione są przywołania bez cytatu ${ }^{25}$. Zauważa się jednak, iż w tej liczbie zaledwie cztery razy są cytowania z IV rozdziału Interpretacji Biblii w Kościele: raz

25 Zestawienie cytowań: w VD 29 jest cytowane IBK III.A.3; w VD 30 IBK II.A.2 [x2]; w VD 33 - IBK III.C.1; w VD 37 - IBK II.A.2; II.B.2; w VD 44 - IBK I.F; w VD 53 III.B.3 - IBK III.B.3; IV.C.1; w VD 114 - IBK IV.B [x2]; w VD 115 - IBK IV.B. Odniesienie do IBK bez cytatu w VD 3 (przyp. 8); 32; 44. 
w związku z liturgią (IBK IV.C.1 w VD 53) i trzykrotnie w relacji do inkulturacji (IBK IV.B [x2] w VD 114 oraz w VD 115). Można na tej podstawie sądzić, że adhortacja Verbum Domini w istotny sposób pogłębia, ale też przewyższa propozycje pastoralne PKB. Teza ta zostanie potwierdzona w kontekście krytycznych uwag poczynionych wcześniej wobec dokumentu Interpretacja Biblii w Kościele: najpierw jego struktury, następnie rozumienia obecności Biblii w duszpasterstwie i wreszcie w kilku kwestiach szczegółowych liturgii, katechezy i lectio divina.

\subsection{Układ propozycji pastoralnych w adhortacji Verbum Domini}

Dla papieża Benedykta XVI lektura Biblii jest „spotkaniem $\mathrm{z}$ wydarzeniem, z Osobą, która nadaje życiu nową perspektywę, a tym samym decydujące ukierunkowanie" (VD 11). „Dzięki Niemu [Chrystusowi] wiara przybiera kształt spotkania z Osobą, której powierzamy własne życie" (VD 25). Spotkanie Chrystusa w słowie Pisma ma rodzić w wierzącym zachwyt i świadectwo (por. VD 11) ${ }^{26}$. Przedmiotem zachwytu jest osoba Jezusa i objawiony w Nim Boży plan zbawienia. Tylko osobiste doświadczenie Chrystusa w słowie Pisma może prowadzić do świadectwa. Podążając za strukturą adhortacji Verbum Domini, osobowe i dialogiczne spotkanie z „Verbum Dei” (rozdz. I adhortacji), uobecnia się w przestrzeni wspólnoty Kościoła jako „domu Słowa”, przez co należy mówić o „Verbum in Ecclesia” (rozdz. II adhortacji). Nie jest to jednak kres słowa Bożego, gdyż te, objawione w osobie Chrystusa, jest „Verbum mundo” (rozdz. III adhortacji), które wszyscy wierni mają głosić światu. To dokonuje się nie tyle na płaszczyźnie apologetycznej, lecz przez świadectwo chrześcijańskie, które „nadaje temu sło-

26 Por. Witczyk, „Słowo Boże w życiu chrześcijanina w świetle Verbum Domini", 106. 
wu wiarygodności, by nie jawiło się jako piękna filozofia lub utopia, ale jako rzeczywistość, którą można żyć i dzięki której można żyć" (VD 97).

Ten układ adhortacji Verbum Domini oparty o Verbum-Chrystusa pozwala na klarowny podział pastoralnej obecności Biblii w Kościele. W II rozdziale adhortacji „Verbum in Ecclesia" papież Benedykt rozróżnia:

- „liturgię jako uprzywilejowaną przestrzeń słowa Bożego” (VD 52-71), w ramach której porusza kwestię sakramentów (nie tylko Eucharystii, ale również sakramentu pokuty i sakramentu chorych), lekcjonarza, homilii, liturgii godzin i animacji liturgicznej;

- „animację biblijną duszpasterstwa” (VD 72-89), podnosząc m.in. temat katechezy, formacji biblijnej chrześcijan, roli słowa Bożego na drogach różnego powołania (także małżeństwa i rodziny), lectio divina i modlitwy maryjnej.

Natomiast w rozdziale III zatytułowanym „Verbum mundo" papież Benedykt XVI, zwracając uwagę na kulturotwórczą rolę Biblii w świecie, odnosi się m.in. do kwestii inkulturacji i tłumaczeń Biblii, do środków społecznego przekazu i dialogu międzyreligijnego. Tymczasem znaczenie Biblii dla ekumenizmu zostaje poruszone w I rozdziale adhortacji. W ujęciu papieża ruch ekumeniczny nie jest jeszcze jedną formą działalności pastoralnej Kościoła, lecz stanowi działanie mające "na celu pełne wyrażenie jedności wszystkich wierzących w Chrystusa” (VD 46).

Zaprezentowana powyżej struktura adhortacji Verbum Domini pozwoliła przezwyciężyć niespójności i powtórzenia obecne w rozdziale IV dokumentu PKB, w którym omawia się różne formy obecności Biblii w Kościele.

\subsection{Biblijna animacja duszpasterstwa}

Adhortacja Verbum Domini odrzuca pokusę dychotomii między apostolatem biblijnym i działalnością pastoralną Kościoła. Benedykt XVI postuluje duszpasterstwo biblijne 
„nie jako jedną z form duszpasterstwa, lecz jako biblijną animację całego duszpasterstwa. Nie chodzi więc o zorganizowanie paru dodatkowych spotkań w parafii lub diecezji, ale o zweryfikowanie, czy zwyczajna działalność naszych wspólnot chrześcijańskich, w parafiach, w stowarzyszeniach i ruchach rzeczywiście ma na celu osobiste spotkanie z Chrystusem, objawiającym się nam w swoim słowie" (VD 73). Sformułowanie o "biblijnej animacji całego duszpasterstwa” jest bez wątpienia rewolucyjne, gdyż każe porzucić spojrzenie instrumentalne na Biblię w duszpasterstwie zwyczajnym oraz odejść od redukcyjnego mówienia o duszpasterstwie biblijnym jako jeszcze jednej formie duszpasterstwa nadzwyczajnego (specjalistycznego).

Od strony pastoralnej istotne jest tworzenie grup biblijnych, w których kładzie się nacisk na odpowiednią formację i duchowość biblijną. Jednakże obok tych działań konieczne jest wychodzenie ku już istniejącym ruchom i stowarzyszeniom kościelnym, funkcjonującym $\mathrm{w}$ ramach parafii rozumianej jako wspólnota wspólnot ${ }^{27}$. Ważna jest też sugestia Benedykta XVI, by „działalność duszpasterska sprzyjała powstawaniu licznych małych wspólnot «składających się z rodzin, zakorzenionych w parafiach albo związanych z różnymi ruchami kościelnymi i nowymi wspólnotami», które szerzyłyby formację, modlitwę i poznawanie Biblii według wiary Kościoła” (VD 73). Tę myśl podejmuje dalej, kiedy „wyraża pragnienie, aby w każdym domu była Biblia i by była przechowywana w sposób godny, by można ją było czytać i posługiwać się nią w modlitwie” i zaleca „tworzenie małych wspólnot, złożonych z rodzin, aby modlić się

27 Dotyczy to również pobożności ludowej, której różne formy są na stałe obecne w życiu parafialnym. Jako że „w słowie biblijnym pobożność ludowa znajdzie niewyczerpane źródło natchnienia, niedościgłe wzorce modlitwy oraz owocne propozycje tematyczne", papież Benedykt postuluje, by „przy okazji pielgrzymek, szczególnych świąt, misji ludowych, dni skupienia i specjalnych dni pokuty, wynagrodzenia i przebaczenia" były „momenty przeznaczone na głoszenie i słuchanie słowa Bożego" (VD 65). 
i rozważać wspólnie odpowiednie fragmenty Pisma” (VD 83). Takie rodzinne ujęcie małych wspólnot w jasny sposób podpowiada kluczową dla życia parafii dynamikę „wspólnot podstawowych" postulowanych przez dokument PKB (por. IBK IV.C.3).

\subsection{Biblia w liturgii}

Fragment adhortacji poświęcony obecności Biblii w liturgii przewyższa swoją spójnością, głębią i perspektywicznością analogiczne omówienie w dokumencie PKB z 1993 r. (IBK IV.C.1). Mówiąc o ubiblijnieniu duszpasterstwa, papież Benedykt XVI podkreśla, że „uprzywilejowanym miejscem dla głoszenia, słuchania i celebrowania słowa Bożego jest liturgia” (VD 72). W tym kontekście pojawia się apel papieża, który „wzywa pasterzy Kościoła i współpracowników duszpasterskich do takiego formowania wszystkich wiernych, by potrafili rozsmakować się w głębokim sensie słowa Bożego, przedstawianego w liturgii podczas całego roku i ukazującego podstawowe tajemnice naszej wiary. Od tego uzależnione jest również właściwe podejście do Pisma Świętego" (VD 52).

Dla animacji biblijnej w ramach liturgii szczególne znaczenie ma homilia, która ma „za zadanie dopomagać pełnemu zrozumieniu oraz oddziaływaniu słowa Bożego na życie wiernych" (VD 59). Papież Benedykt XVI odchodzi o wyliczania negatywnych przykładów wykorzystania Biblii w homilii, jak czyniła to PKB. Postuluje za to opracowanie dyrektorium homiletycznego, które byłoby pomocą dla kaznodziei w jak najlepszym wykonaniu powierzonego im zadania głoszenia słowa Bożego (VD 60) ${ }^{28}$. Homilie mają skupiać się z jednej strony na orędziu ewangelicznym, z drugiej zaś strony aktualizować przesłanie Pisma Świętego (por. VD 59). Równocześnie Benedykt XVI wskazuje na potrzebę ce-

28 Postulat został zrealizowany przez Kongregację ds. Kultu Bożego i Dyscypliny Sakramentów w 2014 r. 
lebracji słowa Bożego podczas sprawowania „innych sakramentów, w szczególności tych, które wiążą się z uzdrowieniem" - sakramentu pokuty i pojednania oraz sakramentu namaszczenia chorych (VD 61) ${ }^{29}$.

\subsection{Lectio divina - modlitewna lektura Biblii}

Ubiblijnieniu liturgii mają też służyć celebracje słowa Bożego (por. VD 65), w tym szczególnie modlitewne czytanie słowa Bożego w ramach lectio divina, prowadzonej zarówno indywidualnie, jak i wspólnotowo (por. VD 86-87). Tu zauważa się olbrzymi postęp w stosunku do dokumentu PKB. Benedykt XVI buduje pewną analogię między lectio divina a adoracją eucharystyczną. „Podobnie jak adoracja eucharystyczna przygotowuje liturgię eucharystyczną, towarzyszy jej i ją pogłębia, tak i modlitewna lektura osobista i wspólnotowa przygotowuje do tego, co Kościół celebruje, głosząc słowo Boże podczas liturgii, towarzyszy temu i to pogłębia” (VD 86). Tylko lectio divina otrzymała w adhortacji Benedykta XVI pogłębienie stricte metodologiczne (por. VD 87), co tylko potwierdza wagę, jaką papież przypisuje modlitewnej lekturze Pisma Świętego w krzewieniu duchowości biblijnej.

\subsection{Narracyjna katecheza biblijna}

W przypadku katechezy Benedykt XVI odwołuje się do spotkania Jezusa $\mathrm{z}$ uczniami idącymi do Emaus

29 W przypadku sakramentu pojednania i pokuty kontakt penitenta ze słowem Bożym może mieć miejsce już podczas rachunku sumienia, którego podstawą może być odpowiedni tekst Pisma Świętego. Możliwość sięgnięcia po odpowiedni tekst biblijny przewiduje również obrzęd pojednania jednego penitenta, jakkolwiek najwyraźniejsze powiązanie tego sakramentu ze słowem Bożym ma miejsce w obrzędzie pojednania wielu penitentów z indywidualną spowiedzią i rozgrzeszeniem, który włącza w liturgię sakramentu wspólnotowe słuchanie słowa Bożego. 
(Łk 24,13-32) (VD 74). Widzi w tym zdarzeniu „w pewnym sensie wzór katechezy, w której centrum jest «wyjaśnianie Pism», jakie potrafi dać jedynie Chrystus (por. Łk 24,27-28), ukazując w sobie samym ich spełnienie". Jezus nie ogranicza się tylko do odczytania słowa Pisma i zinterpretowania go - „rodzi [bowiem w ten sposób] nową nadzieję [...] czyniącą z uczniów przekonanych i wiarygodnych świadków Zmartwychwstałego". To spotkanie na drodze do Emaus stanowi w pewnym sensie model narracyjnej katechezy biblijnej ${ }^{30}$, który wychodzi naprzeciw naturze dialogicznej Biblii.

Konkludując prezentację animacji biblijnej duszpasterstwa zaproponowanej w adhortacji Verbum Domini, należy podkreślić, iż jej wnioski pastoralne bazują na teologii słowa Bożego. Przedstawione postulaty odnoszące się do animacji biblijnej duszpasterstwa przekraczają redukcjonistyczne i instrumentalne podejście do Biblii prezentowane w dokumencie Interpretacja Biblii w Kościele. Biblia nie jest dodatkiem do duszpasterstwa, ale jego źródłem i istotą. Rozwiązania pastoralne wysunięte przez papieża Benedykta XVI są wynikiem interdyscyplinarnych poszukiwań, przez co spojrzenie pastoralne na liturgię czy katechezę jest spójne i dojrzałe hermeneutycznie. Propozycje zawarte w adhortacji otwierają nowe możliwości animacji biblijnej w wielu obszarach życia Kościoła, by wspomnieć liturgię (Biblia nie tylko w Eucharystii, ale również w innych sakramentach i pobożności ludowej), lectio divina (istotne dopowiedzenia metodologiczne) i katechezę (propozycja modelu narracyjnego katechezy biblijnej).

30 Szerzej o modelu biblijnej katechezy narracyjnej wykorzystującej narzędzia stosowane w analizie narracyjnej, przełożone na metody aktywizujące stosowane w katechezie, por. Pikor, „Narracyjny model katechezy biblijnej. Część I”, 9-17; „Część II: Założenia metodologiczne”, 3-11; „Część III: Perspektywy rozwoju”, 4-12. 


\section{ZAKOŃCZENIE}

Dokument Papieskiej Komisji Biblijnej Interpretacja Biblii w Kościele stanowi zwieńczenie odnowy biblijnej, która miała miejsce w XX wieku. Czwarty rozdział tego dokumentu ma charakter pastoralny. Pozostając w ciągłości z soborową konstytucją Dei verbum, w dokumencie PKB pojawiają się nowe elementy mówiące o miejscu Biblii w Kościele. Dotyczy to przede wszystkim aktualizacji i inkulturacji Pisma Świętego. Nowością jest też bezpośrednie przywołanie lectio divina jako modlitewnej lektury Pisma Świętego sugerowanej przez Vaticanum II. W odniesieniu do liturgii PKB podąża tropem wskazanym przez Sobór Watykański II, zwracając uwagę przede wszystkim na znaczenie nowego lekcjonarza w uprzystępnieniu wiernym Pisma Świętego. Podobnie też w kwestii katechizacji i przepowiadania PKB pozostaje w nurcie nauczania soborowego i posoborowego. Dla posługi pastoralnej istotne znaczenie mają praktyczne wskazania dotyczące apostolatu biblijnego, przede wszystkim odnośnie do wspólnot podstawowych czytających Biblię. Analiza czwartego rozdziału dokumentu PKB przyniosła również pewne uwagi krytyczne wobec zgłaszanych tam postulatów. Słabością tego dokumentu jest bez wątpienia pisanie go z perspektywy biblistów, bez ściślejszej współpracy z teologami pastoralnymi różnych specjalności. Ten zasadniczy mankament zostaje przezwyciężony w adhortacji Verbum Domini, która ukazała się 17 lat po dokumencie Interpretacja Biblii w Kościele. Przedstawione przez papieża Benedykta XVI postulaty odnoszące się do animacji biblijnej duszpasterstwa pokazują, że Biblia nie jest dodatkiem do duszpasterstwa, ale stanowi jego źródło i istotę. Propozycje zawarte w adhortacji Verbum Domini otwierają nowe możliwości animacji biblijnej w wielu obszarach życia Kościoła, by wspomnieć liturgię czy katechezę. W perspektywie przyszłości wydaje się, że 
to właśnie adhortacja Verbum Domini, a nie dokument Interpretacja Biblii w Kościele będzie wyznaczała kierunki animacji biblijnej duszpasterstwa.

\section{BIBLIOGRAFIA}

Benedykt XVI, Adhortacja apostolska „Verbum Domini”. O Stowie Bożym wżyciu i misji Kościota (Kraków: Wydawnictwo M 2010).

Chmiel J., „W 50. rocznicę wydania encykliki Divino afflante Spiritu", Ruch Biblijny i Liturgiczny 46 (1993) 170-175.

Chmiel J., „Pismo święte w duszpasterstwie”, Interpretacja Biblii w Kościele. Dokument Papieskiej Komisji Biblijnej z komentarzem biblistów polskich (przekł. i red. R. Rubinkiewicz) (RSB 4; Warszawa: Vocatio 1999) 273-279.

Enchiridion Biblicum. Documenti della Chiesa sulla Sacra Scrittura. Edizione biblingue (Bologna: Edizioni Dehoniane 1993).

Grzybek S., „Pius XII a Biblia”, Ruch Biblijny i Liturgiczny 11 (1958) 466-475.

Interpretacja Biblii w Kościele. Dokument Papieskiej Komisji Biblijnejz komentarzem biblistów polskich (przekł. i red. R. Rubinkiewicz) (RSB 4; Warszawa: Vocatio 1999) 24-100.

Haręzga S., Biblia w Kościele (Biblioteka Horyzontów wiary; Kraków: WAM 1998).

Jan XXIII, Aby byli jedno... Wybór przemówień (Warszawa: Instytut Wydawniczy PAX 1979).

Janicki J., „Obrzędy liturgii Mszy świętej”, Msza święta (red. W.J. Świerzawski) (Misterium Christi 3; Zawichost - Kraków - Sandomierz: Wyd. Diec. Sandomierz 2012) 263-305. Jan Paweł II, „Przemówienie na temat interpretacji Biblii w Kościele", Interpretacja Biblii w Kościele. Dokument Papieskiej Komisji Biblijnej z komentarzem biblistów polskich (przekł. i red. R. Rubinkiewicz) (RSB 4; Warszawa: Vocatio 1999) 9-20. 
Klich A.E., Pismo Święte w polskiej katechezie posoborowej. Studium egzegetyczno-katechetyczne (Duc in Altum 3; Kraków: Wydawnictwo Naukowe PAT 2005).

Kudasiewicz J., „Proforystyka pastoralna”, Wstęp ogólny do Pisma Świętego (red. J. Szlaga) (Warszawa: Pallottinum 1986) 221-275.

Muszyński H., „Chrystus żyjący w swoim słowie. Konstytucja dogmatyczna Dei Verbum - 20 lat po soborze”, Studia Pelplińskie 17 (1986) 161-177.

Papieska Komisja Biblijna, Biblia a moralność. Biblijne korzenie postęowania chrześcijańskiego (Kielce: Verbum 2009). Pikor W. „Narracyjny model katechezy biblijnej. Część I:

Kontekst biblijno-katechetyczny", Katecheta 55/2 (2011) 9-17.

Pikor W., „Narracyjny model katechezy biblijnej. Część II:

Założenia metodologiczne", Katecheta 55/3 (2011) 3-11.

Pikor W., „Narracyjny model katechezy biblijnej. Część III:

Perspektywy rozwoju", Katecheta 55/4 (2011) 4-12.

Pytel J.K., „Wykorzystanie Pisma Świętego w Lectio divina”, Interpretacja Biblii w Kościele. Dokument Papieskiej Komisji Biblijnej z komentarzem biblistów polskich (przekł. i red. R. Rubinkiewicz) (RSB 4; Warszawa: Vocatio 1999) 218-222.

Sławiński, H., „Znaczenie lekcjonarza mszalnego w kaznodziejstwie", Studia Wtoctawskie 6 (2003) 386-403.

Sobór Watykański II, Konstytucje, dekrety, deklaracje. Tekst polski. Nowe ttumaczenie (Poznań: Pallotinum 2002).

Teologia pastoralna. II. Teologia pastoralna szczegótowa (red. R. Kamiński) (Lublin: Wydawnictwo KUL 2002).

Witczyk H., „W czterdziestolecie konstytucji Dei Verbum.

Osiaggnięcia i aktualne wyzwania", Wierność i aggiornamento. Wokót recepcji Soboru Watykańskiego II (red. G. Kucza) (Studia i Rozprawy WT UŚ w Katowicach 32; Katowice: Księgarnia św. Jacka 2006) 136-151.

Witczyk H., „Słowo Boże w życiu chrześcijanina w świetle Verbum Domini", Kerygma - Biblia - katecheza (red. 
R. Czekalski) (Studia Katechetyczne 8; Warszawa: Wydawnictwo UKSW 2012) 103-112.

$Z$ badań nad Biblia (red. D. Piekarz) (Prace Katedry Teologii i Informatyki Biblijnej Wydziału Teologicznego Papieskiej Akademii Teologicznej w Krakowie 2; Kraków: Wydawnictwo Naukowe PAT 1998).

Ks. Wojciech Pikor, profesor zwyczajny w Katedrze Biblistyki Wydziału Teologicznego UMK w Toruniu, rektor Wyższego Seminarium Duchownego Diecezji Peplińskiej. W swoich badaniach koncentruje się na księgach prorockich Starego Testamentu (przede wszystkim Księga Izajasza i Księga Ezechiela), analizie narracyjnej i retorycznej tekstów biblijnych oraz katechezie biblijnej. W ostatnim czasie opublikowat m.in. książkę The Land of Israel in the Book of Ezekiel (LHB/ OTS 667; New York - London: T\&T Clark 2018). 